\title{
Cytotoxic Activity of Extract and Active Fraction of Turbinaria decurrens Bory on Colon Cancer Cell Line HCT-116
}

\author{
Actividad Citotóxica del Extracto y la Fracción Activa de Turbinaria decurrens \\ Bory en la Línea Celular de Cáncer de Colon HCT-116
}

Astria Deviyani Zakaria; Katrin Basah \& Anton Bahtiar

DEVIYANI, Z. A.; BASAH, K. \& BAHTIAR, A. Cytotoxic activity of extract and active fraction of Turbinaria decurrens bory on colon cancer cell line HCT-116. Int. J. Morphol, 36(3):979-983, 2018.

SUMMARY: Turbinaria deccurrens Bory contains bioactive compound that is beneficial for health. Turbinaria deccurrens Bory is one of many species of brown seaweed that grows in Indonesian marine life and has been known to have cytotoxic activity. The aim of this study is to determine fucoxantin content and the cytotoxic activity of extract and fraction T. decurrens on colon cancer cell lines. Cytotoxic assay of ethanolic extract, $n$-hexane, ethyl acetate and ethanolic fractions against HCT-116 by MTS assay using Cell Counting Kit-8 (CCK-8). Fucoxantin content in extract and fraction were analyzed using Reversed-Phase High Performance Liquid Chromatography (RP-HPLC) analysis. Extract and fraction of T. decurrens contain fucoxanthin with the highest content of fucoxanthin was in ethyl acetate fraction. CCK-8 assay showed that extract, n-hexane and ethyl acetate fraction inhibited the growth of HCT-116. Brown seaweed Turbinaria decurrens was potential as an anticolon cancer agent.

KEY WORDS: Brown seaweed; Turbinaria decurrens; Colon cancer; HCT-116; Fucoxanthin.

\section{INTRODUCTION}

As a maritime country Indonesia has abundant biodiversity including seaweeds or algae. Seaweeds contain various compounds as primary and secondary metabolites. Primary metabolites such as polysaccharides including alginat, carrageenan and agar, have been commercial used in food, nutraceutical, cosmetic and agricultural industries. However secondary metabolites are still less used. Therefore the economic value of brown seaweed is lower than red or green seaweed. So the aim of this study was to find the bioactivity of extract and fraction of brown seaweed.

Six species of brown seaweed (Sargassum ilicifolium, Sargassum binderi, Turbinaria decurrens, Turbinaria ornata, Padina australis and Hormophyta triquetra) has been studied the cytotoxicity activity to T47D and HeLa cell line. Turbinaria decurrens showed the cell growth inhibition for both cell lines. T. decurrens also showed the antioxidant activity and contain high fucoxanthin (Nursid et al., 2013). Fucoxanthin is the main component of carotenoid nonprovitamin A, with C42-H58O6 formula (Kim et al., 2012).
Fucoxanthin showed cytotoxic effects by inducing apoptosis of prostate cancer cell line PC-3 (Kotake-Nara et al., 2001), leukemia HL-6 (Nakazawa et al., 2009), and 6 colorectal cell lines, Caco-2, WiDr, HCT116, DLD-1, SW620, Colo205, Caco-2 cell lines (Takahashi et al., 2015). Turbinaria decurrens Bory also contain fucoidan that has been studied showing neuroprotective (Meenakshi et al., 2016) and hepatoprotective effects (Meenakshi et al., 2014).

Cancer is one of the leading causes of morbidity and mortality worldwide, 8.8 million deaths in 2015, colorectal cancer causes 774,000 deaths (WHO, 2017). Colon cancer can be prevented by selecting the appropriate foods and the lifestyle. The most effective treatment is surgical removal, and patients whose tumour cannot be removed are treated using chemotherapy and radiotherapy. Unfortunately, the five-year survival rate for metastatic colon cancer is below $10 \%$ (Chen \& Huang, 2009). Therefore, this study used Turbinaria decurrens to study the activity to another cell line, that was colon cancer cell line HCT-116. 


\section{MATERIAL AND METHOD}

Chemicals. Ethanol, n-hexane, ethyl acetate, aquadest, methanol, acetonitrile (Merck), Counting Cell Kit-8 (Dojindo Laboratories, Japan), 5-Fluorouracil (5-FU) (Kalbe), fucoxanthin (Sigma).

Brown seaweed. Brown seaweed Turbinaria decurrens was collected from Binuangen Beach, Banten, Indonesia. The collected seaweeds were washed with tap water and distilled water to remove salt and other debris then packed with iced to keep cool during the transportation to the laboratory.

Extraction and fractination. Two kg wet weight Fresh seaweed Turbinaria decurrens Bory were extracted with 70 $\%$ ethanol. Filtrate were evaporated in evaporator with vacuum. Crude extract was dissolved by aquadest $(100 \mathrm{ml})$ and fractionated by liquid-liquid fractionation by $\mathrm{n}$-hexane and ethyl acetate (each $100 \mathrm{ml} \times 3$ ) respectively and both evaporated in vacuum to get $n$-hexane and ethyl acetate fractions. Ethanol-aqueous residue was evaporated to get ethanol fraction.

Analysis of fucoxanthin in the extract and fraction. Fucoxanthin content of the extract was analyzed using High Performance Liquid Chromatography (HPLC). Fucoxanthin in extract expressed as mg per 1 gram ethanolic extract and in fraction expressed as mg per 1 gram fraction. HPLC condition used the method as described by Noviendri et al. (2011). HPLC analysis carried out using a Shimadzu system equipped with a pump (LC-20AT), UV/Vis detector (SPD20A). Reversed-phase HPLC (RP-HPLC) analysis were carried out using a C18 RP column, $5 \mu \mathrm{m}$ particle size, 250 $\mathrm{mm}$ x 4,6 mm (YMC Co., LTD). Fucoxanthin content was determined with methanol-acetonitrile $(7: 3, \mathrm{v} / \mathrm{v})$ as the mobile phase at a flow rate $0.5 \mathrm{ml} / \mathrm{min}$. The amount of fucoxanthin was quantified from the peak area using a standard curve with fucoxanthin standard (Sigma).
Cytotoxic assay. A Cell Counting Kit-8 (CCK-8) assay (Dojindo Laboratories, Japan) were used to measure the cytotoxicity of ethanolic extract and n-hexane, ethyl acetate and ethanolic fraction of T. decurrens on human colon cancer cell HCT-116. 100 mL HCT-116 cell line (1000 cell/well) were grown in 96-well plates and preincubated for $24 \mathrm{~h}$ (temperature at $37{ }^{\circ} \mathrm{C}, 5 \% \mathrm{CO}_{2}$ ). After $24 \mathrm{~h}$, treated with $100 \mathrm{~mL}$ extract and fraction with various concentrations (0$240 \mathrm{mg} / \mathrm{mL}$ ). 5-fluorourasil (5-FU) was used as positive control and distributed with various concentrations 0-625 $\mathrm{mg} / \mathrm{mL}$ (Davoodi et al., 2013) and fucoxanthin standard (Sigma) as marker substance of brown seaweeds with various concentrations 0 - $150 \mathrm{mg} / \mathrm{mL}$. All samples then incubated for $48 \mathrm{~h}$ in incubator. The extent of cell growth was assessed using a CCK- 8 assay, CCK-8 solution $(10 \mathrm{~mL})$ was added to each well, followed by incubation for $1 \mathrm{~h}$ at $37^{\circ} \mathrm{C}$. The absorbance at $450 \mathrm{~nm}$ was determined by multiplate reader. The inhibition percentage of cell growth were calculated with formula: (A-D)-(B-C)/(A-D) x $100 \%$, where $\mathrm{A}=$ control cell absorbance, $\mathrm{B}=$ compounds absorbance, $\mathrm{C}=$ controls compound absorbance, and $\mathrm{D}=$ control media absorbance. The inhibition concentration 50 (IC50) value is defined as the concentration of compound which inhibited $50 \%$ of the cell growth (Nursid et al.).

\section{RESULTS AND DISCUSSION}

Fucoxanthin content. Fucoxanthin is main component of non-provitamin A carotenoid and has free radical scavenging activity due to unusual allenic double bonds $(\mathrm{C}=\mathrm{C}=\mathrm{C})$ that is believed to be responsible for its higher antioxidant activity (Agatonovic-Kustrin et al., 2016). Fucoxanthin has been investigated as antitumor and cancer-preventative function that indicate inducing G1 cell-cycle arrest and apoptosis in various cell lines (Satomi, 2017).

Ethanol solvent was chosen for extraction because it

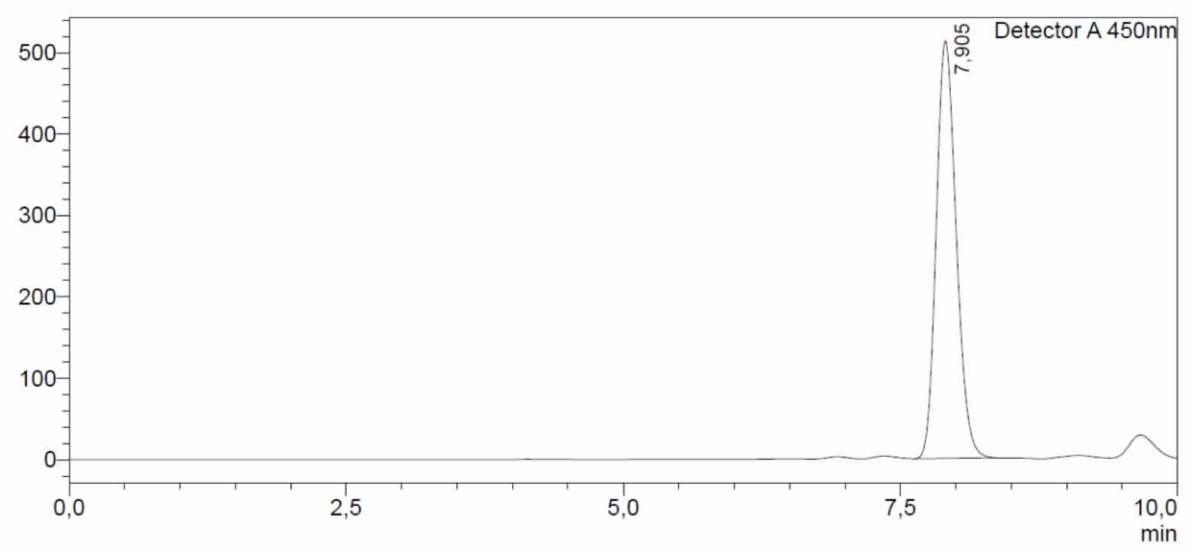

Fig. 1. Chromatograms of $25 \mathrm{ug} / \mathrm{ml}$ fucoxanthin standard. 
Table I. Yield percentage and fucoxanthin content of $T$. decurrens extract and fractions

\begin{tabular}{lcc}
\hline & $\begin{array}{c}\text { Yield } \\
(\%)\end{array}$ & $\begin{array}{c}\text { Fucoxanthin content } \\
(\mathrm{mg} / \mathrm{g})\end{array}$ \\
\hline Extract & 1.4 & 9.851 \\
$n$-hexane fraction & 19.3 & 9.869 \\
Ethyl acetate fraction & 21.13 & 10.148 \\
Ethanol fraction & 39.27 & 9.781 \\
\hline
\end{tabular}

provided the best fucoxanthin extraction yield from Phaeodactylum tricornutum $(15.71 \mathrm{mg} / \mathrm{g}$ freeze-dried sample weight (Kim et al.). Fucoxanthin content was analyzed using HPLC in ethanolic extract, $n$-hexane, ethyl acetate and ethanolic fraction of Turbinaria decurrens. Based on retention time of fucoxanthin standard, peak of fucoxanthin detected in $7.8 \mathrm{~min}$. Peak in thats retention time also showed in extract and fraction (Fig. 2a-d).

The results showed that of fucoxanthin content in the extract and fraction as shown in Table I were analysis using chromatogram of fucoxanthin standard. Fucoxanthin standard has retention time $7.905 \mathrm{~min}$ as shown in Figure 1, the extract and all fractions have similar chromatogram at the RT around 7.9 min as shown by red arrow in Figure 2. From this result the fucoxanthin concentration of the ethanolic extract, ethyl acetate fraction, $\mathrm{n}$-hexane fraction, ethanolic fraction are $9.851 \mathrm{mg} / \mathrm{g}, 10.148 \mathrm{mg} / \mathrm{g}, 9.869 \mathrm{mg} / \mathrm{g}$ and 9.781 $\mathrm{mg} / \mathrm{g}$ respectively.
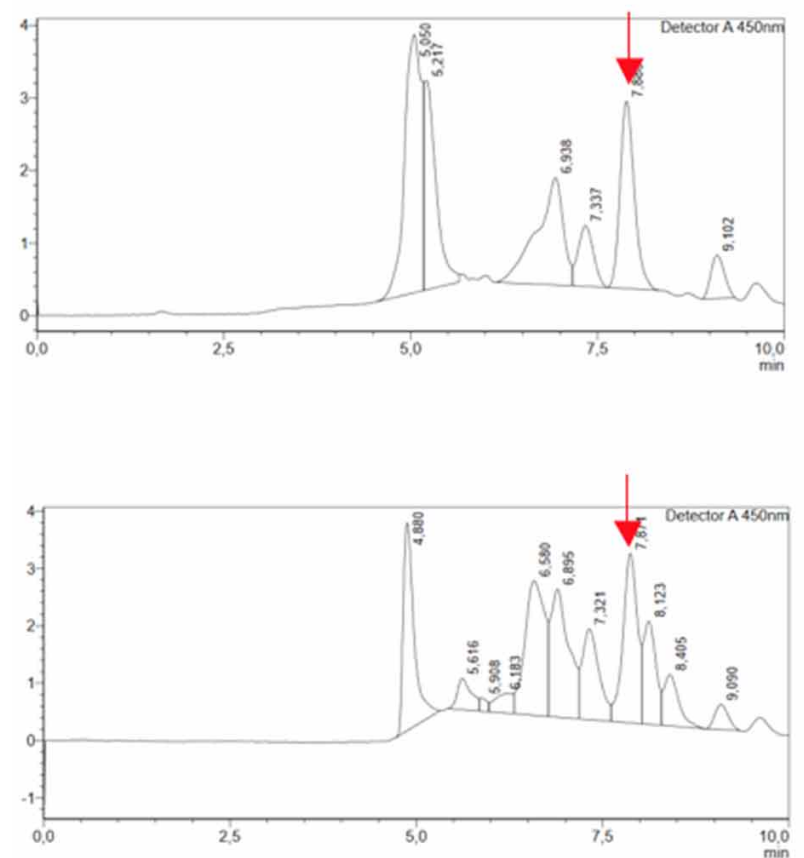

Cytotoxicity test. Cytotoxic activity of the extract and fractions of $T$. decurrens was evaluated using CCK- 8 assay. After $48 \mathrm{~h}$ of treatment, the mortality of HCT-116 cell was shown by treatment of extract, n-hexane and ethyl acetate fraction, but didn't show inhibition activity from ethanolic fraction (Table II). IC50 values of extract and n-hexane, ethyl acetate fraction was $215 \mu \mathrm{g} / \mathrm{ml}, 1.512 \mu \mathrm{g} / \mathrm{ml}, 3.058 \mu \mathrm{g} / \mathrm{ml}$, respectively.

Table II. Cytotoxicity against HCT-116 cell line.

\begin{tabular}{|c|c|}
\hline & $\begin{array}{c}\mathrm{IC}_{50} \\
(\mu \mathrm{g} / \mathrm{ml})\end{array}$ \\
\hline Extract & 281,16 \\
\hline$n$-hexane fraction & 16,38 \\
\hline Ethyl acetate fraction & 11,24 \\
\hline Ethanol fraction & 483,32 \\
\hline Fucoxanthin & 12,37 \\
\hline 5-FU & 11.84 \\
\hline
\end{tabular}

Cytotoxic activity from $T$. decurrens to another cancer cell line has been reported. Methanolic extract showed cytotoxic activity to T47D, HepG2 and C26 cells with IC50 value were 172,360 , and $330 \mu \mathrm{g} / \mathrm{ml}$. After fractionation of the Turbinaria decurrens Bory extract, the cytotoxicity increased with IC50 of n-hexane, ethyl acetate and methanol fraction were 43.1, 51.9, $383.0 \mu \mathrm{g} / \mathrm{ml}$ (Nursid et al.). This research indicated that extract $T$. decurrens was potential as an anticancer agent, $n$-hexane and ethyl acetate fraction also can be considered for the development of anticancer agent.
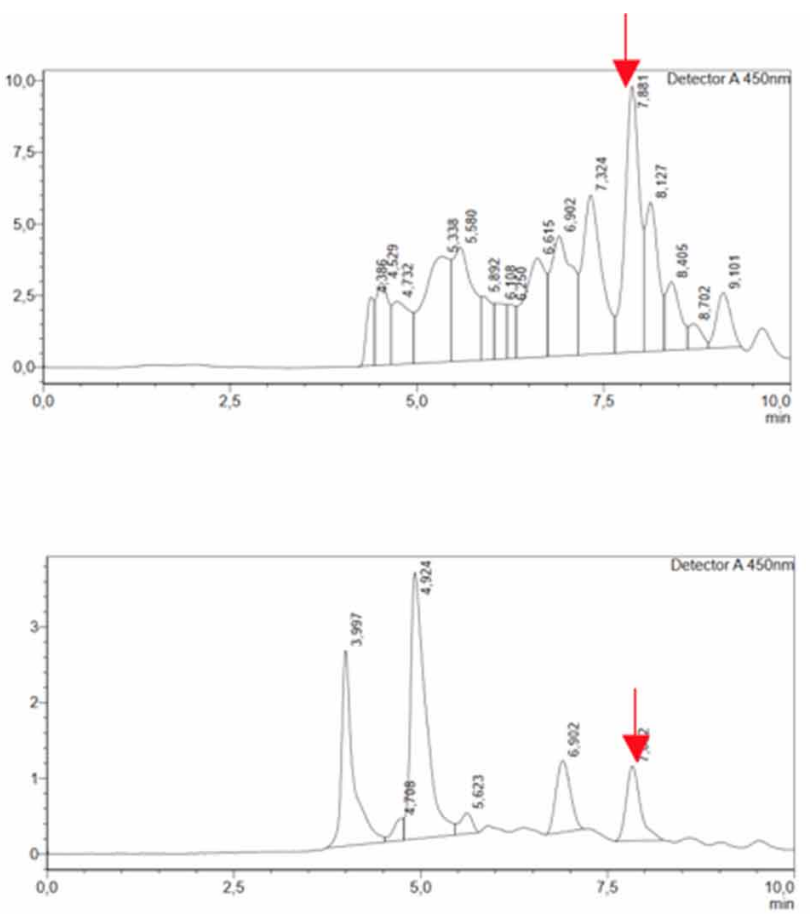

Fig. 2. Chromatograms of fucoxanthin in ethanolic extract (a), ethyl acetate (b), n-hexane (c), and ethanolic (d) fraction of $T$. decurrens. *red arrow indicated fucoxanthin 
Cytotoxic activity of $T$. decurrens was compared with fucoxanthin standard and 5-fluorouracil as a positive control. Cytotoxic activity of extract was lower than fucoxanthin and 5-FU, while n-hexane and etyl acetate fraction seem higher than 5-FU but still lower than fucoxanthin.

Fucoxanthin showed inhibition values (IC50) of HCT-116 cell at $1.207 \mu \mathrm{g} / \mathrm{ml}$, which means fucoxanthin is a potential anticancer agent and supported by antioxidant activity that has IC50 values at $1.0974 \mathrm{ppm}$ (Zailanie et al., 2015). Antiproliferative effect of cancer cell line also has been evaluated by Asai et al. (2003) and IC50 values on the proliferation of PC-3 cells was 4,6 $\mu \mathrm{M}$ for fucoxanthin. IC50 -of 5-FU was $11.843 \mu \mathrm{g} / \mathrm{ml}$, its value was not significantly different from Davoodi et al., that showed IC50 of 5-FU after $48 \mathrm{~h}$ treatment to HCT-116 was $10 \mu \mathrm{g} / \mathrm{ml}$.

From cytotoxic test, it's seem not only fucoxanthin that affected the cytotoxic activity because it's not showed in ethanolic fraction although it has fucoxanthin. Cytotoxic activity in brown seaweed was not always related to fucoxanthin because brown seaweed has another component, such as steroid, poysaccharide and phenol. 3-keto-22-epi28-nor-cathasteron and kolest-4-ene-3,6-dion has cytotoxic activity to HEPG-2 and HCT 116. Fucosterol also showed cytotoxic activity to HT-29, Caco-2 dan T47D (Hussain et al., 2016). Fucoidan, a polysaccharide, has cytotoxic activity to HCT-15 with IC50 value was $75 \mu \mathrm{g} / \mathrm{mL}$ (Somasundaram et al., 2016). Flavonoid that isolated from Turbinaria ornata showed antiproliferation to A549, PC-3, HCT-15 dan MG63 cells. Bromophenol had IC50 value at $10 \mu \mathrm{g} / \mathrm{mL}$ to HT1080 and HCT-8 cells (Kim, 2011).

\section{CONCLUSION}

Extract, n-hexane and ethyl acetat fraction of Turbinaria decurrens Bory had cytotoxic activity against HCT-116 cell line, and contain fucoxanthin in extract and fraction.

DEVIYANI, Z. A.; BASAH, K. \& BAHTIAR, A. Actividad citotóxica del extracto y la fracción activa de Turbinaria decurrens bory en la línea celular de cáncer de colon HCT-116. Int. J. Morphol, 36(3):975-978, 2018.

RESUMEN: Turbinaria deccurrens Bory contiene compuestos bioactivos que son beneficiosos para la salud. Turbinaria deccurrens Bory es una de muchas especies de algas pardas que crecen en aguas marinas de Indonesia y se ha estudiado su actividad citotóxica. El objetivo de este estudio fue determinar el con- tenido de fucoxantina y la actividad citotóxica del extracto y la fracción de T. decurrens en líneas celulares de cáncer de colon. Se llevó a cabo un ensayo citotóxico de extracto etanólico, nhexano, acetato de etilo y fracciones etanólicas contra HCT-116 mediante ensayo MTS utilizando Cell Counting Kit-8 (CCK-8). El contenido de fucoxantina en el extracto y la fracción se analizaron usando cromatografía líquida de alta resolución de fase reversa (RP-HPLC). El extracto y la fracción de $T$. decurrens contienen fucoxantina conmayor contenido de fucoxantina en la fracción de acetato de etilo. El ensayo CCK-8 mostró que la fracción de extracto, n-hexano y acetato de etilo inhibía el crecimiento de HCT-116. El alga marrón Turbinaria decurrens es un agente potencial contra el cáncer de colon.

PALABRAS CLAVE: Alga marrón; Turbinaria decurrens; Cáncer de colon; HCT-116; Fucoxantina.

\section{REFERENCES}

Agatonovic-Kustrin, S.; Morton, D. W. \& Ristivojevic, P. Assessment of antioxidant activity in Victorian marine algal extracts using high performance thin-layer chromatography and multivariate analysis. J. Chromatogr. A, 1468:228-35, 2016.

Asai, A.; Sugawara, T.; Ono, H. \& Nagao, A. Biotransformation of fucoxanthinol into amarouciaxanthin A in mice and HepG2 cells: formation and cytotoxicity of fucoxanthin metabolites. Drug Metab. Dispos., 32(2):205-11, 2003.

Chen, J. \& Huang, X. F. The signal pathways in azoxymethane-induced colon cancer and preventive implications. Cancer Biol. Ther., 8(14):1313-7, 2009.

Davoodi, H.; Hashemi, S. R. \& Seow, H. F. 5-fluorouracil induce the expression of TLR4 on HCT116 colorectal cancer cell line expressing different variants of TLR4. Iran. J. Pharm. Res., 12(2):453-60, 2013.

Hussain, E.; Wang, L. J.; Riaz, S.; Butt, G. Y. \& Shi, D. Y. A review of the components of brown seaweeds as potential candidates in cancer therapy. R. S. C. Adv., 6:12592-610, 2016.

Kim, S. K. Handbook of Marine Macroalgae: Biotechnology and Applied Phycology. Oxford, Wiley-Blackwell, 2011.

Kim, S. M.; Jung, Y. J.; Kwon, O. N.; Cha, K. H.; Um, B. H.; Chung, D. \& Pan, C. H. A potential commercial source of fucoxanthin extracted from the microalga Phaeodactylum tricornutum. Appl. Biochem. Biotechnol., 166(7):1843-55, 2012.

Kotake-Nara, E.; Kushiro, M.; Zhang, H.; Sugawara, T.; Miyashita, K. $\&$ Nagao, A. Carotenoids affect proliferation of human prostate cancer cells. J. Nutr., 131(12):3303-6, 2001.

Meenakshi, S.; Umayaparvathi, S.; Saravanan, R.; Manivasagam, T. \& Balasubramanian, T. Hepatoprotective effect of fucoidan isolated from the seaweed Turbinaria decurrens in ethanol intoxicated rats. Int. J. Biol. Macromol., 67:367-72, 2014.

Meenakshi, S.; Umayaparvathi, S.; Saravanan, R.; Manivasagam, T. \& Balasubramanian, T. Neuroprotective effect of fucoidan from Turbinaria decurrens in MPTP intoxicated Parkinsonic mice. Int. J. Biol. Macromol., 86:425-33, 2016.

Nakazawa, Y.; Sashima, T.; Hosokawa, M. \& Miyashita, K. Comparative evaluation of growth inhibitory effect of stereoisomers of fucoxanthin in human cancer cell lines. J. Funct. Foods, 1(1):88-97, 2009.

Noviendri, D.; Jaswir, I.; Salleh, H. M.; Taher, M.; Miyashita, K. \& Ramli, N. Fucoxanthin extraction and fatty acid analysis of Sargassum binderi and S. duplicatum. J. Med. Plants Res., 5(11):2405-12, 2011. 
DEVIYANI, Z. A.; BASAH, K. \& BAHTIAR, A. Cytotoxic activity of extract and active fraction of Turbinaria decurrens bory on colon cancer cell line HCT-116. Int. J. Morphol, 36(3):979-983, 2018.

Nursid, M.; Wikanta, T. \& Susilowati, R. Antioxidant activity, cytotoxicity and fucoxanthin content of brown algae extract collected from Binuangen coast, Banten. J. P. B. Kelaut. Perikan., 8(1):73-84, 2013.

Satomi, Y. Antitumor and Cancer-preventative Function of Fucoxanthin: A Marine Carotenoid. Anticancer Res., 37(4):1557-62, 2017.

Somasundaram, S. N.; Shanmugam, S.; Subramanian, B. \& Jaganathan, R. Cytotoxic effect of fucoidan extracted from Sargassum cinereum on colon cancer cell line HCT-15. Int. J. Biol. Macromol., 91:121523, 2016.

Takahashi, K.; Hosokawa, M.; Kasajima, H.; Hatanaka, K.; Kudo, K.; Shimoyama, N. \& Miyashita, K. Anticancer effects of fucoxanthin and fucoxanthinol on colorectal cancer cell lines and colorectal cancer tissues. Oncol. Lett., 10(3):1463-7, 2015.

World Health Organization (WHO). Cancer. Geneva, World Health Organization (WHO), 2017. Available from: http://www.who.int/ mediacentre/factsheets/fs297/en/

Zailanie, K.; Kartikaningsih, H.; Kulsum, U. \& Sanjaya, Y. A. Fucoxanthin effects of pure sargassum filipendula extract toward HeLa cell damage. Int. J. PharmTech Res., 8(3):402-7, 2015.

\author{
Corresponding author: \\ Anton Bahtiar \\ Department of Pharmacology \\ Faculty of Pharmacy \\ Universitas Indonesia \\ Kampus UI Depok 16424 \\ INDONESIA
}

Email: anton.bahtiar@farmasi.ui.ac.id

Received: 04-11-2017

Accepted: 30-01-2018 